\title{
Optimalisasi Lingkungan Sekitar Sekolah Sebagai Alternatif Laboratorium IPA
}

\author{
${ }^{1}$ Mohammad Abdul Khafid, ${ }^{2}$ Lukman Hakim, ${ }^{3}$ Imam Mahmudi \\ ${ }^{1,2}$ Institut Agama Islam Negeri Salatiga \\ ${ }^{3}$ Institut Agama Islam Negeri Kudus \\ Email: mudongcompany01@gmail.com
}

Article Info
Article History
Received: 31 Juli 2019
Revised: 14 September
2019
Published: 30 September
2019
Keywords
School environment,
Sciencer laboratory,
Environmental based
laboratory

Informasi Artikel

Sejarah Artikel

Diterima:

Direvisi:

Dipublikasi:

Kata kunci

Lingkungan

laboratorium

laboratorium

lingkungan

\begin{abstract}
Science not only discusses abaout material science but also abaout practice or direct experience. Learners participate in contests that hold concretely, according to the theories discussed (in the context of the elementary school science that is about the environment situation, or that is in everyday life). Problems in the field, in fact, most teachers only discuss the theories in the book and only apply the lessons in the classroom. This was triggered because there were no adequate laboratory facilities at the school, as well as lack of motivation to create learning innovations. This study uses a qualitative research method with the phenomenology approach. Based on the results of the study, actually the solution to this problem is very close to the teacher, namely the environment around the school with various objects and phenomena. The existence of this school environment both yard, garden and school field can be a very appropriate vehicle as an alternative to laboratory learning, or with other terms such as environment-based laboratories.
\end{abstract}

\section{Abstrak}

Ilmu Pengetahuan Alam tidak hanya membahas tentang materi akan tetapi juga tentang praktik atau pengalaman secara langsung. Peserta didik seharusnya diajak melaksanakan praktik secara riil, konkrit, sesuai dengan teori yang sedang dipelajari (Dalam konteks IPA SD yaitu tentang keadaan lingkungan sekitar, atau yang ada di kehidupan sehari-hari). Permasalahan yang ada di lapangan, pada sekolah, kenyataanya, sebagian guru hanya mengajarkan teori yang ada di buku dan IPA, hanya menerapkan pembalajaran di dalam ruang kelas. Hal tersebut dipicu berbasis karena tidak adanya fasilitas laboratorium yang memadai di sekolah, serta minimnya motivasi untuk membuat inovasi pembelajaran. Penelitian ini menggunakan metode penelitian kualitatif dengan pendekatan phenomenology. Berdasarkan hasil penelitian, sebenarnya solusi dari permasalahan ini sangat dekat dengan bapak/ibu guru, yaitu lingkungan sekitar sekolah dengan berbagai objek dan fenomenanya. Adanya lingkungan sekolah ini baik halaman, kebun dan lapangan sekolah ini dapat menjadi wahana yang sangat tepat sebagai alternatif laboratorium pembelajaran, atau dengan istilah lain yaitu sebagai laboratorium berbasis lingkungan.

Sitasi: Khafid, Mohammad Abdul et. al. (2019). Optimalisasi Lingkungan Sekitar Sekolah Sebagai Alternatif Laboratorium IPA. Science Education and Application Journal (SEAJ). Vol. 1. No. 2: 74-83

\section{PENDAHULUAN}

Mata pelajaran IPA adalah termasuk yang ada di dalam kurikulum tingkat dasar. IPA merupakan mata pelajaran yang bersifat konkrit. Dalam kegiatan belajarnya membutuhkan laboratorium khusus, atau minimal alat peraga yang tepat. Selama ini pembelajaran IPA kebanyakan hanya berfokus pada teori yang ada di buku-buku pegangan siswa. Seorang guru hanya mengandalkan buku ajar dan buku pegangan siswa, maka hal ini hanya akan meningkatkan kemampuan kognitif peserta didik. Peserta didik hanya mengetahui definisidefinisi sesuai yang terdapat dalam buku. 
Ilmu IPA mengajarkan kompleksitas kehidupan yang di kembangkan dari penelitianpenelitian. Penelitian-penelitian ini yang menelurkan hal-hal baru. Maka dari itu praktikum atau eksperimen dinilai menjadi penting dalam kegiatan belajar mengajar IPA. Melalui kegiatan praktikum atau eksperimen siswa dapat secara konkrit mempelajari obyek yang sedang ia pelajari. Baik menggunakan indra sendiri ataupun dengan alat bantu. Maka dari itu, sarana prasarana sekolah yang mumpuni sangatlah menunjang keberhasilan dari kegiatan ini (Salabi, A. 2016). Kegiatan praktikum dapat meningkatkan motifasi siswa dalam belajar. Melalui praktikum (di laboratorium) siswa mendapatkan kesempatan untuk mencari tahu sendiri dari rasa keingintahuan yang mereka rasakan. Mereka akan menemukan pengetahuanya sendiri melalui kegiatan eksperimen atau hanya dengan pengamatan dan kesimpulan. Dengan praktikum juga, siswa dapat mengembangkan ketrampilan dasar di seorang ilmuan (Emda, A. 2014).

Dengan begitu, siswa akan mampu mengamati suatu obyek dengan cermat, mengukur secara akurat menggunakan alat, menggunakan alat dengan aman sesuai prosedur, mendeskripsikan hasil pengamatan atau eksperimen, serta dapat meneceriatakan kepada teman-temanya tentang pengalaman belajarnya. Praktikum menjadi proses untuk pembelajaran secara ilmiah, cara terbaik pembelajaran ilmiah adalah hanya dengan menjadikan siswa sebagai ilmuan. proses ini sangat dimungkinkan ranah psikomotor peserta didik akan meningkat, karena siswa dilibatkan secara langsung dalam semua kegiatan. Konsep keilmuan IPA dapat dicapai dengan maksimal adalah salah satunya menggunakan metode praktik. Komponenkomponen kegiatan praktikum ini dapat dilaksanakan di laboratorium (Muna, I. A. 2016). Maka dari itu, sesungguhnya pembelajaran IPA sangatlah membutuhkan hadirnya laboratorium. Sudah sepatutnya siswa mempelajari IPA dengan praktik. Dengan praktik siswa mampu memahami materi-materi yang di sampaikan guru dengan mudah. Serta memudahkan siswa memahami bahan ajar yang di sampaikan oleh guru. Praktik ini dilakukan di tempat yang khusus yaitu laboratorium IPA. Hadirnya laboratorium di suatu satuan pendidikan menjadi sangat di butuhkan.

Standar proses pendidikan merupakan salah satu standar yang mengalami perubahan pada Kurikulum 2013 yang sedang diterapkan saat ini. Salah satu perubahan dalam standar tersebut adalah terkait kegiatan pembelajaran, yaitu pembelajaran ditujukan untuk mengembangkan potensi peserta didik agar memiliki kemampuan hidup sebagai pribadi dan warga negara yang beriman, produktif, kreatif, inovatif, dan afektif, serta mampu berkontribusi pada kehidupan masyarakat, berbangsa, bernegara, dan berperadaban dunia (Fikri, 2019). Kurikulunm 2013 (K13) sangat menekankan pembelajaran yang mengembangkan ranah aspek psikomotor. Pembelajaran sains tidak bisa dilepaskan dari pemberian pengalaman belajar kepada siswa secara langsung. Melalui metode inkuiri, siswa melakukan kegiatan pengamatan, penelitian, eksperimen dan penyelidikan tentang fenomena alam.

Laboratorium menjadi salah satu tolak ukur kualitas suatu lembaga pendidikan. Semakin lengkap ketersediaan alat dan tempat praktik suatu lembaga pendidikan menjadi indikator bahwa kesiapan sekolah tersebut dalam melaksanakan pembalajaran sangat baik. Namun, hal ini sangatlah jarang kita temui di sekolah-sekolah yang berada di pinggiran kota. Sekolah tingkat dasar, baik SD atau MI yang berada di pinggiran kota, hanya beberapa saja yang mempunyai peralatan untuk praktik IPA. Banyak diantara mereka hanya mempunyai sangat sedikit peralatan, bahkan ada yang hanya mempunyai peta dan globe. Sedangkan kebutuhan alat peraga, tempat praktik serta perlengkapanya sudah sangat mendesak. Hal ini diantaranya dikarenakan karena finansial sekolah yang kurang mumpuni, sehingga ada keterbatasan dalam mewujudkan kebutuhan pembelajaran yang berupa laboratorium.

Mata pelajaran IPA pada tingkat SD/MI pada umumnya masih membahas tentang lingkungan di sekitar kita. Misalnya materi tentang mengenal sifat benda dan perubahanya, bumi dan alam sekitar, mengenal energi serta menerapkan konsep energi, serta masih banyak lainya yang materi tersebut hanya berkutat pada kehidupan sehari-hari kita. Materi-materi ini 
jika kita mengamati secara kritis, maka kita akan menemukan di tempat-tempat yang sering kita temui di kehidupan sehari-hari kita. Dengan begitu tempat-tempat yang bisa kita temui tersebut bisa kita manfaatkan sebagai tempat belajar yang tepat. Misalnya anak-anak di ajak ke lapangan di pagi hari, untuk mengamati air yang ada di daun-daun. Jika kita mengacu pada materi-materi IPA yang di sajikan di sekolah tingkat dasar, kita akan menemui kemudahan dalam menentukan tempat praktikum. Karena pada dasarnya tempat praktikum atau bisa di katakan laboratorium secara arti lebih luas, bisa bertempat dimanapun tempatnya, selama di tempat tersebut terdapat alat peraga yang bisa digunakan untuk observasi atau eksperimen. Menggunakan lingkungan sekitar yang bisa diberdayakan dan dimaksimalkan sebagai alat pembelajaran, misalnya taman, ladang, sungai, halaman sekolah, dapur, lapangan, bahkan ruangan kelas itu sendiri. Penggunaan lingkungan sekitar tersebut merupakan penggunaan laboratorium yang berbasis lingkungan. Penelitian ini bertujuan untuk mengetahui strategi Penggunaan Lingkungan Sekitar sebagai Laboratorium IPA.

\section{METODE}

Penelitian ini menggunakan metode penelitian kualitatif dengan pendekatan phenomenologi. Hanya ingin mengeksplore fonomena yang terjadi serta mendalami fenomenafenomena yang ada. Data dalam penelitian ini dikumpulkan menggunakan tehnik wanwancara, observasi serta dokumentasi. Tehnik wawancara digunakan untuk mendalami fenomena yang terjadi. Adapaun mengenai analisis data menggunakan perbandingan teori-teori yang relevan dengan realita yang ada.

\section{HASIL DAN PEMBAHASAN \\ Mata Pelajaran IPA Sekolah Dasar}

Mata pelajaran IPA adalah salah satu mata pelajaran yang ada pada kurikulum pendidikan tingkat Dasar. Pelajaran IPA merupakan suatu ilmu pengetahuan yang bersifat dinamis, dan selalu berkembang sesuai dengan kemajuan Ilmu Pengetahuan dan Teknologi (IPTEK). Ilmu IPA mempelajari tentang hidup dan kehidupan dengan segala kompleksitasnya, yang diperoleh melalui eksperimen sehingga didapat temuan-temuan baru. Eksperimen perlu dilakukan karena sesuai dengan hakikat siswa yang mempelajari Biologi dapat mengadakan kontak langsung dengan obyek yang diselidiki dengan menggunakan indera sendiri atau dengan pertolongan alat bantu. Oleh sebab itu, diperlukan sarana dan prasana sekolah yang memadai untuk membantu proses pembelajaran IPA (Salabi, A. 2016). Pembelajaran IPA pada hakikatnya membutuhkan laboratorium dalam prakteknya. Laboratorium sangat penting dalam melaksanakan pembelajaran IPA karena melalui laboratorium siswa dapat melakukan praktek secara langsung tentang materi IPA yang dipelajari. IPA tidak hanya mempelajari suatu hal secara teori saja, akan tetapi pembelajaran IPA sudah sepatutnya dilakukan dengan praktek untuk memudahkan siswa dalam memahami setiap materi/bahan ajar yang disampaikan oleh guru. Praktek dilakukan di suatu tempat khusus yaitu laboratorium IPA. Laboratorium IPA sebagai suatu tempat menggali ilmu pengetahuan yang berusaha secara sistematis untuk memahami mengapa dan bagaimana manusia bekerja secara sistematis.

Keberadaan sebuah laboratorium IPA disekolah menjadi semakin vital manakala diberlakukannya kurikulum 2013 yang sangat menekankan pada aspek psikomotorik siswa dalam belajar. Hakikat pendidikan sains tidak lepas dari pemberian pengalaman belajar siswa secara langsung dan hukum-hukum alam melalui serangkaian kegiatan inkuri meliputi pengamatan, penelitian dan penyelidikan tentang fenomena alam. Kegiatan pembelajaran praktik berdasarkan inkuri siswa dilatih untuk mengembangkan keterampilan ilmiah seperti mengamati, mengumpulkan data, merakit, merancang percobaan dan melatihmenarik kesimpulan. Arti pembelajaran sains tidak dipisahkan dengan kerja praktik, oleh karena itu peralatan pendukung kerja praktik merupakan sarana untuk mengembangkan kompetensi siswa dalam bidang sains dan teknologi. 


\section{Tata Kelola Laboratorium}

\section{A. Pengertian}

Laboratorium merupakan salah satu sarana pembelajaran selayaknya sebuah kelas yang dipakai untuk melakukan kegiatan belajar mengajar, sama halnya seperti yang dinyatakan oleh Rahmawati laboratorium dapat berubah fungsi menjadi kelas jadi semua fasilitas yang ada bisa digunakan secara optimal (Rahmawati, Y. 2010). Salah satu indikator dari kualitas sebuah lembaga pendidikan, dapat dilihat melalui ketersediaan fasilitas dan sarana penunjang pembelajaran, hal ini sesuai dengan pernyataan bahwa: "kualitas sebuah lembaga pendidikan diukur berdasarkan ketersediaan fasilitas dan sarana pembelajaran" (Rizki, 2013). Lebih lanjut Hafiar et all., menjelaskan bahwa ketersediaan fasilitas belum dianggap mencukupi, mengingat ketersediaan fasilitas, masih membutuhkan adanya pengawasan dan perawatan agar kondisi fasilitas dapat tetap terjaga dalam kondisi layak (Hafiar, 2017). Pembelajaran IPA untuk menerapkan metode ilmiah dibutuhkan laboratorium sebagai sarana atau tempat untuk melakukan kegiatan pratikum. Pemanfaatan laboratorium atau kegiatan pratikum merupakan bagian dari proses belajar mengajar. Menurut Muna melalui kegiatan praktikum, siswa dapat membuktikan konsep atau teori yang sudah ada dan dapat mengalami proses atau percobaan itu sendiri, kemudian mengambil kesimpulan, sehingga dapat menunjang pemahaman siswa terhadap materi pelajaran (Muna, 2016). Dalam hal ini, jika siswa lebih paham terhadap materi kuliah diharapkan hasil belajarnya dapat meningkat.

Kegiatan praktikum IPA adalah kegiatan yang dilakukan untuk menemukan suatu konsep/prinsip baru bagi siswa yang didasarkan pada konsep atau prinsip IPA yang telah ada dan dirumuskan oleh para ahli dibidang IPA. Apabila ditinjau dari segi siswa, maka kegiatan praktikum ini adalah kegiatan untuk menemukan konsep atau prinsip, dan bila ditinjau dari segi ahli, maka kegiatan ini adalah proses verifikasi konsep atau prinsip. Praktikum ini sendiri merupakan salah satu metode pembelajaran yang dapat menumbuh kembangkan rasa ingin tahu siswa, aktif, kreatif, inovatif, dan kejujuran ilmiah dalam menghadapi suatu masalah dalam realita kehidupan (Muna, 2016).

\section{B. Fungsi}

Laboratorium harus dilengkapi dengan berbagai sarana prasarana untuk kebutuhan percobaan. Laboratorium sebagai tempat kegiatan riset, penelitian, percobaan, pengamatan, serta pengujian ilmiah menurut Emda memiliki banyak fungsi, yaitu (Emda, A. 2014):

1. Menyeimbangkan antara teori dan praktik ilmu dan menyatukan antara teori dan prakti.

2. Memberikan keterampilan kerja ilmiah bagi para peneliti, baik dari kalangan siswa, siswa, dosen, atau peneliti lainnya. Hal ini disebabkan laboratorium tidak hanya menuntut pemahaman terhadap objek yang dikaji, tetapi juga menuntut seseorang untuk melakukan eksperimentasi.

3. Memberikan dan memupuk keberanian para peneliti (yang terdiri dari pembelajar, peserta didik, siswa, dosen dan seluruh praktisi keilmuan lainnya) untuk mencari hakikat kebenaan ilmiah dari suatu objek keilmuan dalam lingkungan alam dan lingkungan sosial.

4. Menambah keterampilan dan keahlian para peneliti dalam mempergunakan alat media yang tersedia di dalam laboratorium untuk mencari dan menentukan kebenaran ilmiah sesuai dengan berbagai macam riset ataupun eksperimentasi yang akan dilakukan.

5. Memupuk rasa ingin tahu kepada para peneliti mengenai berbagai macam keilmuan sehingga akan mendorong mereka untuk selalu mengkaji dan mencari kebebaran ilmiah dengan cara penelitian, ujicoba, maupun eksperimentasi.

6. Laboratorium dapat memupuk dan membina rasa percaya diri para peneliti dalam keterampilan yang diperoleh atau terhadap penemuan yang didapat dalam proses kegiatan kerja di laboratorium. 
7. Laboratoriun dapat menjadi sumber belajar untuk memecahkan barbagai masalah melalui kegiatan praktik, baik itu masalah dalam pembelajaran, masalah akademik, maupun masalah yang terjadi ditengah masyarakat yamg membutuhkan penanganan dengan uji laboratorium.

8. Laboratorium dapat menjadi sarana belajar bagi para siswa, siswa, dosen, aktivis, peneliti dan lain-lain untuk memahami segala ilmu pengetahuan yang masih bersifat abstrak sehingga menjadi sesuatu yang bersifat konkret dan nyata.

Secara garis besar lebih lanjut Emda menjelaskan bahwa fungsi laboratorium adalah sebagai berikut (Emda, A. 2014):

1. Memberikan kelengkapan bagi pelajaran yang telah diterima sehingga antara teori dan praktek bukan merupakan dua hal yang terpisah.

2. Memberikan ketrampilan kerja ilmiah bagi siswa.

3. Memberikan dan memupuk keberanian untuk mencari hakikat kebenaran ilmiah dari suatu objek dalam lingkungan alam dan lingkungan sosial.

4. Menambah keterampilan dalam menggunakan alat dan media yang tersedia untuk mencari dan menemukan kebenaran.

5. Memupuk rasa ingin tahu siswa/ siswa sebagai modal sikap ilmiah seorang calon ilmuan.

Memupuk dan membina rasa percaya diri sebagai akibat keterampilan yang diperoleh, penemuan yang didapat dalam proses kegiatan kerja laboratorium.

\section{Unsur-Unsur}

Pengelolaan laboratorium berkaitan dengan pengelola dan pengguna, fasilitas laboratorium (bangunan, peralatan laboratorium, specimen IPA), dan aktivitas yang dilaksanakan di laboratorium yang menjaga keberlanjutan fungsinya. Para pengelola laboratorium hendaknya memiliki pemahaman dan keterampilan kerja di laboratorium, bekerja sesuai tugas, tanggung jawabnya, dan mengikuti peraturan. Pengelola laboratorium di sekolah. Secara umum sebagai berikut: (1) Kepala sekolah (2) wakil kepala sekolah; (3) koordinator laboratorium; (4) penanggung jawab laboratorium; (5) laboran. Para pengelola tersebut mempunyai tugas dan kewenangan yang berbeda, namun tetap sinergi dalam pencapaian tujuan bersama yang telah ditetapkan. Koordinator laboratorium adalah unsur pelaksana dan pengembang akademik laboratorium, mengkoordinasikan dan mengembangkan fungsi laboratorium untuk kegiatan pembelajaran dan penelitian. Tugas laboran adalah membantu koordinator laboratorium dalam mengkoordinasikan dan mengembangkan fungsi laboratorium untuk kegiatan pembelajaran dan penelitian (Elseria. 2016).

1. Pengelolaan Laboratorium

Berikut adalah persyatatan yang harus dipenuhi dalam pembangunan sebuah laboratorium sekolah yang sehat dan sesuai standar yaitu (Yaman, E. 2016):

1. Tidak terletak di arah angin, untuk menghindarkan pencemaran udara, gas sisa reaksi kimia yang kurang sedap agar tidak terbawa angin ke ruangan - ruangan yang lain.

2. Mempunyai jarak yang cukup jauh dari sumber air bersih, untuk menghindari pencemaran pada sumber air.

3. Mempunyai saluran pembuangan limbah sendiri, untuk menghindari pencemaran saluran air penduduk.

4. Mempunyai jarak cukup jauh dari bangunan yang lain, untuk mendapatkan ventilasi dan penerangan alami yang optimum, jarak minimal sama dengan tinggi bangunan terdekat, atau kira - kira 3 meter.

5. Terletak pada bagian yang mudah dikontrol dalam kompleks, dalam hubungannya dengan pencegahan terhadap pencurian, kebakaran, dan sebagainya 
6. Tidak mengarah datangnya sinar matahari secara langsung. Jendela tidak menghadap ke arah datangnya sinar matahari (utara/ selatan)

7. Laboratorium terletak dibagian tengah pojok kiri dan pojok kanan yang terdapat dibagian belakang Jauhi dari keramaian / kebisingan

8. Posisi ventilasi cahaya, jendela, dan pintu terletak disebelah utara dan selatan. Posisi pintu sejajar dengan jendela

9. Tidak boleh terkena sinar matahari secara langsung kedalam laboratorium karena ada sebagian zat yang terkena sinar matahari akan meledak ataupun berubah zatnya

10. Laboratorium jauh dari kelas agar orang yang bekerja di laboratorium bisa bekerja dengan tenang dan nyamanSebaiknya di laboratorium terdapat blower (penghisap udara)

11. Memiliki Bangku praktikum, Meja praktikum, Wastafel, minimal 8 buah yang terletak dikiri,kanan, dan tengah, Papan tulis, Almari gantung, yang bisa dijangkau agar ruang gerak kegiatan tidak terganggu, papan tulis, Lampu (Penerangan), Tempat sampah pemadam kebakaran, minimal terletak di depan dan minimal 1 buah

12. Terdapat pintu minimal 2 buah, dan pintu menghadap keluar agar saat terjadi kecelakaan di laboratorium, pintu akan mudah dilalui (tidak tertutup saat dilewati beramai - ramai)

13. Kotak P3K beserta perlengkapannya

14. Goni yang dibasahkan, apabila kebakaran bersumber dari bahan bakar minyak, dan juga bisa dipadamkan dengan menggunakan pasir, dengan meletakkan pasir didalam bak pasir yang terletak dibelakang supaya tidak mengganggu kegiatan

15. Bak air, yang terletak di belakang.

16. Memiliki Ruang praktek, Ruang persiapan, Ruang penyimpanan, Ruang gelap, Ruang timbang, Ruang specimen dan kultur, serta Rumah kaca (green house).

\section{Laboratorium Berbasis Lingkungan Sekitar}

Sebelum membahas mengenai peran lingkungan dalam proses pembelajaran IPA terlebih dahulu perlu dipaparkan pengertian lingkungan sekitar. Yang dimaksud dengan lingkungan sekitar yaitu segala sesuatu yang berada diluar/disekitar individu, baik itu berupa makhluk hidup misalnya hewan, tumbuhan atau manusia maupun berupa benda tak hidup berupa tanah, air, udara atau benda apa saja yang berada di sekitar siswa. Pembelajaran IPA dengan memanfaatkan lingkungan sekitar dapat menciptakan kegiatan pembelajaran yang menekankan keterlibatan siswa secara aktif (student centered), yaitu kegiatan eksplorasi, percobaan, diskusi atau kegiatan lain untuk mengungkap fenomena alam atau segala sesuatu yang terjadi dalam aktivitas keseharian dengan memanfaatkan lingkungan sekitar sekitar. Kegiatan belajar lebih ditekankan pada aktivitas kontekstual. Maksud dari kegiatan tersebut adalah apa yang dilakukan siswa di kelas merupakan refleksi aktivitas siswa di lingkungan tempat tinggalnya atau di lingkungan sekolahnya. Dengan demikian aktivitas belajar dapat di dilakukan dalam kelas, di luar kelas, atau di lingkungan sekolah. Dalam belajar menekankan siswa aktif bukan berarti ada kebebasan mutlak bagi siswa dalam berkehendak atau bertingkah laku, namun karena adanya keterbatasan pengetahuan yang dimiliki siswa, maka menuntut peran aktif dan kreativitas guru dalam menentukan strategi pembelajaran.

Situasi belajar aktif tersebut tercipta jika guru memfasilitasi dan memberi kesempatan kepada siswa untuk berbuat atau belajar, Peran Guru sebagai organisator, fasilitator, dan motivator. Dalam pembelajaran IPA yang perlu diperhatikan adalah kesiapan guru dan kreativitas guru untuk menentukan strategi pembelajaran dengan memanfaatkan lingkungan sekitar dan menyiapkan media atau sarana belajar yang bervariasi dari lingkungan sekitar. Hal ini untuk mengatasi kejenuhan pada diri siswa (Sulistyorini. 2006). Kegiatan pembelajaran yang menekankan proses dengan memanfaatkan lingkungan sekitar diharapkan dapat memberi pengalaman konkret bagi siswa, dengan demikian pembelajaran menjadi bermakna dan 
berkualitas. Pembelajaran dikatakan berkualitas jika guru menyajikan permasalahan yang menantang, menyenangkan, memberi kesempatan kepada siswa untuk bereksplorasi, memberi pengalaman sukses, mengembangkan kecakapan berpikir dan dalam pembelajarannya memanfaatkan sumber belajar baik berupa sumber belajar alami maupun hasil desain (Depdiknas. 2006). Lebih lanjut ditegaskan bahwa prinsip pembelajaran yang berkualitas adalah: (1) Siswa terlibat aktif secara intelektual, emosianal untuk melakukan eksplorasi terhadap fenomena alam, (2) siswa dilatih untuk menemukan konsep IPA melalui berbagai cara, misalnya melalui observasi, diskusi, atau melakukan percobaan, (3) memberi kesempatan kepada siswa untuk menyelesaikan tugas bersama, dan (4) untuk menjadi kreatif apabila siswa dibimbing untuk dapat bekerja keras, antusias, dan percaya diri sehingga diharapkan kreatifitas siswa berkembang menjadi lebih baik.

Linkungan sangat penting digunakan dalam proses pembelajaran siswa SD karena dapat digunakan sebagai sasaran belajar, sumber belajar, maupun sebagai sarana belajar.

1. Lingkungan sebagai sasaran belajar. Segala sesuatu di sekitar anak itu merupakan obyek untuk dipelajari/diajarkan kepada anak, atau lingkungan sebagai sasaran belajar bagi anak, misalkan kita mempelajari tentang bagian-bagian tubuh tumbuhan, bagian tubuh hewan atau manusia, mempelajari struktur tanah. Untuk mempelajari materi tersebut di atas maka kita memerlukan tumbuhan, hewan, manusia, atau lahan yang ada di lingkungan sekitar siswa.

2. Lingkungan sebagai sumber belajar. Beberapa sumber belajar misalnya guru, buku-buku, laboratorium, kebun sekolah, tenaga ahli, lingkungan sekitar dan sebagainya. Lingkungan merupakan sumber belajar yang tak habis-habisnya memberikan pengetahuan bagi anak. Lingkungan tersebut semakin digali, semakin banyak yang kita dapatkan, tidak saja bagi IPA itu sendiri tetapi juga berupa sumber dari berbagai ilmu pengetahuan seperti IPS dan Matematika. Misalnya dalam mempelajari pemcemaran lingkungan, dengan memanfaatkan lingkungan yaitu lingkungan yang tercemar dan lingkungan tidak tercemar, maka kita dapat memperoleh informasi secara langsung, dapat membandingkan antara lingkungan yang tercemar dengan lingkungan yang masih bersih atau yang sehat dari lingkungan sekitar.

3. Lingkungan sebagai sarana belajar. Setiap proses belajar memerlukan sarana belajar, misal ruang kelas dengan perabotnya, laboratorium dengan perlengkapannya, perpustakaan dan sebagainya. Lingkungan sebagai sarana belajar yang baik, bahkan lingkungan sekitar yang alami menyediakan bahan-bahan yang tidak usah dibeli, misalnya untuk mempelajari proses fotosintesis pada tumbuhan hijau kita memerlukan cahaya matahari, udara, dan tumbuhan hijau sebagai sarana pembelajaran fotosintesis tersebut. Dalam mempelajari proses pernapasan pada manusia, maka kita memerlukan udara dari lingkungan sekitar. Dengan demikian lingkungan merupakan sarana belajar yang ekonomis (Darmodjo, Hendro, 1993).

Lebih lanjut ditegaskan bahwa belajar dengan memanfatkan lingkungan sekitar dapat mengembangkan aspek pedagogis. Aspek pedagogis yang dapat dikembangakan melalui interaksi dengan lingkungan adalah:

1. Mengembangkan sikap dan keterampilan. Dengan berinteraksi dengan lingkungan alam sekitar, anak dapat merasakan suasana belajar yang nyata. Belajar dengan memanfaatkan lingkungan maka anak akan dapat melakukan observasi langsung, sehingga mereka terlibat langsung atau mengalami secara langsung dalam proses belajarnya. Hal tersebut tidak akan dialami siswa jika pembelajarannya melalui ceramah. Oleh karena itu belajar melalui interaksi dengan lingkungan sekitar di samping mengembangkan intelektual siswa juga dapat mengembangkan sikap, minat dan keterampilannya.

2. Dapat digunakan bagi siswa dari semua tingkat perkembangan intelektualnya. Lingkungan dapat digunakan sebagai sumber dan sarana belajar dari anak TK sampai perguruan tinggi yang tingkat keluasan dan kedalamannya berbeda. 
3. Dapat menjadi sumber motivasi belajar anak. Lingkungan sekitar selalu mengandung rahasia alam. Kita berhasil menguak sesuatu pengetahuan maka akan segera muncul sesuatu yang baru yang belum diketahui. Hal ini merangsang kepada anak untuk ingin mengetahui yang lebih mendalam dan lebih banyak, mengembangkan sikap ingin tahu.

\section{Strategi Penggunaan Lingkungan Sekitar sebagai Laboratorium IPA}

Srategi Menggunakan lingkungan sekitar dalam proses pembelajaran IPA antara lain meliputi:

1. Gunakan lingkungan sebagai lahan pengembangan keterampilan proses. Dalam proses pembelajaran dengan memanfaatkan lingkungan sekitar, guru dapat membimbing siswa untuk belajar dalam hal mengamati, mengukur, mengklasifikasikan, membuat inferensi dan keterampilan lainnya.

2. Gunakan lingkungan sebagai lahan pengembangan sikap. Pada hakikatnya IPA dapat dipandang dari tiga dimensi yaitu di mensi proses, produk dan pengembangan sikap ilmiah. Sebagai contoh sikap berpikir bebas, sikap tidak purba sangka, dan sebagainya. Termasuk sikap mencintai lingkungan dengan memanfaatkan lingkungan misalnya tugas membuat atau memelihara kebun sekolah, melakukan eksperimen dan sebagainya.

3. Gunakan lingkungan untuk pengayaan. Anak berbeda satu dengan yang lainnya. Ada yang mampu belajar cepat ada yang belajarnya lambat. Perbedaan ini menimbulkan masalah di dalam kelas. Bagi anak yang cedas dia akan lebih cepat selesai mengerjakan sesuatu tugas, maka dengan memanfaatkan lingkungan sekitar maka guru dapat memberikan tugas tambahan berupa pengayaan bagi anak yang cerdas.

Strategi Penggunaan lingkungan menurut kelompok umur. Semakin tinggi umur semakin membutuhkan wawasan lingkungan yang makin luas. Dimulai dari diri sendiri, kelas, gedung sekolah, lingkungan sekolah, seterusnya dari lingkungan yang sempit atau dekat dengan siswa menuju lingkungan yang semakin luas cakupannya. Lingkungan sekitar dapat berupa media pembelajaran, untuk siswa SD dapat dipilih media atau alat/bahan yang sederhana. Pemilihan alat atau media sederhana untuk proses pembelajaran siswa bukan semata-mata karena harganya yang murah tetapi karena didasarkan atas kepentingan perkembangan belajar siswa. Dengan media sederhana yang telah mereka kenal dalam kehidupan sehari-hari maka pusat perhatian siswa akan lebih terpusat pada obyek yang diselidiki, bukan terpesona pada media buatan pabrik. Dalam pembelajaran IPA agar menjadi efektif perlu memanfaatkan lingkungan sekitar dilengkapi dengan lembar kerja siswa.

Lembar kerja siswa (LKS). LKS dapat berupa kertas kosong atau berbentuk formulir untuk ditulisi, digambari atau diisi oleh anak sesuai dengan petunjuk pada LKS. Sebagian guru ada yang menginginkan adanya lembar kerja yang lengkap untuk setiap kegiatan, namun demikian ada juga yang hanya menggunakan lembar tempat mencantumkan data yang diperoleh. Dengan menggunakan LKS sebagai kelengkapan dalam pembelajaran dengan memanfaatkan lingkungan sekitar ada beberapa hal yang perlu diperhatikan, antara lain adalah siswa harus aktif dan guru harus mendapatkan masukan untuk mengevaluasi kegiatan siswa. Manfaat LKS dalam proses pembelajaran antara lain,: 1) memudahkan guru mengelola pembelajaran yaitu mengubah guru sentris menjadi siswa sentris, 2) membantu guru dalam mengarahkan siswa untuk menemukan konsep melalui aktivitasnya baik secatra kelompok maupun individu, 3) LKS dapat digunakan untuk mengembangkan keterampilan proses, 4) LKS memudahkan guru memantau keberhasilan siswa untuk mencapai sasaran belajar. Penampilan LKS harus menarik. LKS yang penuh dengan kata-kata danpertanyaan-pertanyaan yang harus dijawab siswa akan menimbulkan kesan jenuh sehingga membosankan atau tidak menarik. LKS yang penuh dengan gambar saja maka pesan/isinya tidak akan sampai. Jadi yang baik adalah LKS yang memiliki kombinasi antara tulisan dengan gambar dengan proporsi yang seimbang. 


\section{KESIMPULAN (12pt)}

Mata pelajaran IPA merupakan mata pelajaran yang harus banyak melibatkan siswa pada kondisi yang konkrit dan riil. Dengan kondisi yang nyata ini peserta didik mampu secara mudah mengidentifikasi, meneliti, mengamati serta menyimpulkan sendiri apa yang telah dialaminya. Laboratorium merupakan salah satu sumber belajar yang paling efektif untuk kegiatan belajar mengajar mata elajaran IPA. Laboratorium ini harus memenuhi kriteriakriteria khusus. Namun tidak menutup kemungkinan ada inovasi dari guru dalam membentuk laboratorium sendiri. Karena laboratorium dalam arti luas tidak hanya sekelompok perangkat yang harus adadi suatu ruangan khusus, namun lebih kepada tempat dimana ada sesuatu yang bisa di guanakan untuk praktik (mengamati, mengidentifikasi, menganalisis dan menyimpulkan) pada suatu materi tertentu. Lingkungan sekitar merupakan tempat serta media belajar yang sangat tepat bagi peserta didik tingkat dasar. Karena mereka sangat kental dengan kesan kebiasaan sehari-hari. Lingkungan sekitar inilah yang bisa menggantikan peran laboratorium ruangan pada proses pemahaman materi kepada peserta didik. Penggunaan lingkungan sebagai laboratorium IPA, dapat dimulai dengan mengelompokan usia, sesuai kelas atau sesuai kelompok. Hal ini guna memaudahkan dalam pemilihan tempat dan alat, serta supaya tepat sasaran. Dalam pelaksanaanya dapat di pandu mengguanakan LKS yang didesaign o; eh guru sesuai kebutuhan.

\section{SARAN}

Penelitian ini dapat dilanjutkan dengan menggunakan metode pengembangan (reseacrh and developmen). Penelitian bisa difokuskan pada pengembangan bahan ajar maupun lembar kerja siswa (LKS). Dengan adanya pengembangan bahan ajar ataupun LKS, pendidik akan lebih mudah dalam menjalankan kegiatan belajar mengajar yang berbasis laboratorium lingkungan sekitar. Adapun penggunaan laboratorium berbasis lingkungan sekitar ini akan mengalami hambatan dan kesulitan jika lokus atau tempat penelitian dipilih sekolah yang berada di tengah kota ataupun perkotaan. Lingkungan perkotaan peneliti akan kesulitan menemukan lingkungan yang sesuai dengan yang diharapkan, karena penelitian ini membutuhkan lingkungan yang alami.

\section{DAFTAR PUSTAKA (12pt)}

Fikri., A. A., Ismah, V., \& Paidi, P. (2019). Pengembangan perangkat pembelajaran model Guided Inquiry untuk meningkatkan creative thinking Siswa. Thabiea: Journal of Natural Science Teaching. Vol (1)(01): 1-8.

Darmodjo, Hendro, 1993. Pendidikan IPA 2. Jakarta: Depdikbud

Depdiknas. 2006. Peningkatan Kualitas Pembelajaran. Jakarta: Depdiknas Dtjen Dikti

Elseria. 2016. 'Efektifitas Pengelolaan Laboratorium IPA' Manajer Pendidikan. Volume 10. No 1.

Emda, A. 2014. 'Laboratorium Sebagai Sarana Kimia dalam Meningkatkan Pengetahuan dan Keterampilan Kerja Ilmiah'. Lantanida Journal, Vol.2 No.2.

Hafiar, H dan Jimi N. M. 2017. 'Tantangan Optimalisasi Peran Laboratorium TV di Peruguruan Tinggi Profetik’ Jurnal Komunikasi. Vol 10 No. 02 Oktober 2017.

Muna, I. A. 2016. 'Optimalisasai Fungsi Laboratorium IPA Melalui Kegiatan Praktikum Pada Prodi PGMI Jurusan Tarbiyah STAIN Ponorogo'. Kodifikasia, Vol. 10 No.1.

Rahmawati, Y. 2010. Perkembangan Sistem Pendidikan Balai Pondok Pesantren Pabelan (Menuju Pesantren Modern ). Skripsi. Universitas Negeri Semarang

Rizki, J. W. S. (2013). Optimalisasi Fungsi Perpustakaan Perguruan Tinggi, Melalui Peran Pustakawan. Jurnal Al-Kuttab, 1(2).

Salabi, A. 2016. 'Needs Assessment Laboratorium Biologi Pada Madrasah Aliyah negeri (MAN) di Kota Banjarmasin’ Jurnal PTKdan Pendidikan Vol. 2 No. 2. 
Sulistyorini. 2006. Penerapan Active Learning Dalam Pembelajaran Sains di SD dan MI. Makalah disampaikan pada Training For Teacher SD Ilam Terpadu. FIP UNNES

Yaman, E. 2016. 'Pengoptimalan Peran Kepala Laboratorium dalam Menunjang Pembelajaran IPA di SMPN 7 Kubung’ Jurnal Penelitian Guru Indonesia-JPGI (2016) Vol.1. 